\title{
A case report of breast cancer and membranous nephropathy with positive anti phospholipase $\mathrm{A} 2$ receptor antibodies
}

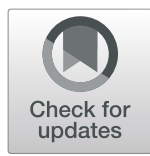

\author{
David Mathew* ${ }^{*}$, Sanjana Gupta and Neil Ashman
}

\begin{abstract}
Background: Testing for antibodies against podocyte phospholipase A2 receptor-1 (PLA2R) allows clinicians to accurately identify primary membranous nephropathy (MN). Secondary MN is associated with a spectrum of pathology including solid organ malignancy. PLA2R positivity in these patients occurs, although no case of PLA2Rpositive MN has been definitively linked to cancer.

Case presentation: We describe a case of biopsy-proven PLA2R-positive MN, in whom invasive ductal carcinoma of the breast was discovered. The patient underwent surgery and adjuvant chemotherapy (including cyclophosphamide) and went into a sustained complete remission of her nephrotic syndrome.

Discussion and conclusions: Case series have reported PLA2R positivity in patients with solid organ malignancy associated MN. Our case is unusual as it is a breast malignancy, and the patients nephrotic syndrome and antiPLA2Rab titres improved with treatment of the cancer. Here we report, to the best of our knowledge, the first case of oestrogen receptor-2 positive breast cancer associated with PLA2R positive MN in a young lady that was treated successfully by treating the malignancy.
\end{abstract}

Keywords: Cyclophosphamide, Malignancy, Membranous, Nephrotic, PLA2R, Primary, Remission

\section{Background}

Antibodies against podocyte phospholipase A2 receptor-1 (PLA2R [1]) were discovered in 2009. Testing for PLA2R antibody allows clinicians to quickly and accurately (specificity approaching $100 \%$ [2]) identify primary membranous nephropathy $(\mathrm{MN})$. Secondary $\mathrm{MN}$ is associated with a spectrum of pathology including solid organ malignancy. PLA2R positivity in these patients occurs, although no case of PLA2R-positive MN has been definitively linked to cancer [3]. We describe a case of biopsy-proven PLA2Rpositive $\mathrm{MN}$, in whom invasive ductal carcinoma of the breast was discovered. The patient underwent surgery and adjuvant chemotherapy (including cyclophosphamide)

\footnotetext{
* Correspondence: David.mathew2@nhs.net

Department of Nephrology, Royal London Hospital, Whitechapel Road, London E1 1FR, UK
}

(c) The Author(s). 2021 Open Access This article is licensed under a Creative Commons Attribution 4.0 International License, which permits use, sharing, adaptation, distribution and reproduction in any medium or format, as long as you give appropriate credit to the original author(s) and the source, provide a link to the Creative Commons licence, and indicate if changes were made. The images or other third party material in this article are included in the article's Creative Commons licence, unless indicated otherwise in a credit line to the material. If material is not included in the article's Creative Commons licence and your intended use is not permitted by statutory regulation or exceeds the permitted use, you will need to obtain permission directly from the copyright holder. To view a copy of this licence, visit http://creativecommons.org/licenses/by/4.0/ The Creative Commons Public Domain Dedication waiver (http://creativecommons.org/publicdomain/zero/1.0/) applies to the data made available in this article, unless otherwise stated in a credit line to the data. 
and HIV serology negative. Anti-Nuclear Antibody negative, Extractable Nuclear Antigen negative, Double stranded DNA negative and Rheumatoid Factor undetectable. Immunoglobulin A $2.33 \mathrm{~g} / \mathrm{L}$, Immunoglobulin G $7.8 \mathrm{~g} / \mathrm{L}$, IgG Subclass $40.349 \mathrm{~g} / \mathrm{L}$, Immunoglobulin M $0.96 \mathrm{~g} / \mathrm{L}, \mathrm{C} 31.46$ $\mathrm{g} / \mathrm{L}, \mathrm{C} 40.47 \mathrm{~g} / \mathrm{L}$. No light chains detected on serum or urine protein electrophoresis.

An anti-PLA2R antibody titre was measured at 178kunits/L by ELISA.

Renal biopsy demonstrated characteristic capillary loop thickening, spike formation on silver stain and positive immunohistochemistry for anti-PLA2Rab with polytypic IgG4. A diagnosis of primary $\mathrm{MN}$ was made.

Her blood pressure and volume overload were controlled on irbesartan and furosemide. Anticoagulation was declined by the patient even when her albumin dropped to $<25 \mathrm{~g} / \mathrm{L}$. The expected hypercholesterolaemia was managed with atorvastatin.

Despite maximal non-immunosuppressive antiproteinuric treatment the patient's nephrosis persisted, and worsened. Her serum albumin fell to $18 \mathrm{~g} / \mathrm{L}$, uPCR increased to $950 \mathrm{mg} / \mathrm{mmol}$ and anti-PLA2Rab rose on serial testing to 448kunits/L. Eleven months after her initial presentation, in this context, it was agreed with her to treat with immunosuppression. Initiation of this regime was delayed at the patients request. Two months after this decision had been made and, prior to the commencement of any immunosuppression therapy, the patient was diagnosed with multifocal grade 2 invasive ductal carcinoma of the right breast. This was estrogen receptor positive and human epidermal growth factor negative and staging revealed no metastatic disease (pT2 pN1 M0).

She underwent curative treatment with a right mastectomy and axillary lymph node clearance followed by chemotherapy and chest wall radiotherapy. Postoperatively and prior to adjuvant chemotherapy with intravenous cyclophosphamide and doxorubicin she remained nephrotic. She then completed 6 cycles of chemotherapy and received a total cyclophosphamide dose of $6.4 \mathrm{~g}$ with doxorubicin $0.64 \mathrm{~g}$.

Clinical improvement of MN timed to successful treatment of the underlying malignancy. After completion of chemotherapy her serum albumin had increased to $34 \mathrm{~g} /$ $\mathrm{L}$, the uPCR had improved to $512 \mathrm{mg} / \mathrm{mmol}$ (peak 1400 $\mathrm{mg} / \mathrm{mmol}$ ) and the anti-PLA2Rab titre fell to $4 \mathrm{kunits} / \mathrm{L}$ (peak titre 674kunits/L). Now, 18 months after completing therapy, her anti-PLA2Rab titre is $<2$, with a normal serum albumin and a reducing urine PCR of $344 \mathrm{mg}$ / mmol. She is now in a sustained partial remission from her MN.

\section{Discussion and conclusions}

Case series have reported PLA2R positivity in patients with solid organ malignancy associated $\mathrm{MN}$. In one [3], only 3 of 10 patients were positive both for serum antiPLA2RAb and histological IgG4. These patients had stomach, lung and larynx malignancies. Our case is unusual as it is a breast malignancy, and her nephrotic syndrome and anti-PLA2Rab titres improved with treatment of the cancer. Additionally, our patient is young whereas the mean age of malignancy associated $\mathrm{MN}$ is 66.

The cyclophosphamide dose used to treat the breast cancer was a lower dose than that used to successfully treat primary $\mathrm{MN}$; however the contribution of this treatment to the resolution of her nephrosis cannot be completely excluded, indeed there are reports of partial remission of MN with Cyclophosphamide doses of less than $3 \mathrm{~g}$ [4]. Although less likely given her high PLA2R titre, a spontaneous remission of primary $\mathrm{MN}$ is also possible independent of the malignancy.

Here we report, to the best of our knowledge, the first case of oestrogen receptor-2 positive breast cancer associated with PLA2R positive MN in a young lady that was treated successfully by treating the malignancy. We caution clinicians that the exclusive use anti-PLA2Rab in determining a diagnosis of primary MN may not be appropriate.

Case series have demonstrated an association between THSD7A and malignancy in MN [5] and the advent of laser capture microdissection and mass spectrometry has led to the identification of NELL1 as a putative biomarker for malignancy associated MN in PLA2R negative patients [6]. It is likely that further targets will be identified in the field of MN in the coming years which will further elucidate the association between this disease and malignancy.

\section{Abbreviations}

eGFR: Estimated Glomerular Filtration Rate; PLA2R: Phospholipase A2 Receptor-1; MN: Membranous Nephropathy; UPCR: urine Protein Creatinine Ratio; NELL1: Nerve Epidermal Growth Factor Like 1;

THSD7A: Thrombospondin type-1 domain containing 7A

\section{Acknowledgements}

N/A.

\section{Authors' contributions}

DM, SG and NA all contributed to literature search and writing up of case report. All authors read and approved the final manuscript. NA was the responsible clinician for this patients care.

\section{Funding}

No funding was obtained for this study.

Availability of data and materials

Data referred to from previously published work is referenced in the body of the text.

\section{Declarations}

Ethics approval and consent to participate

No ethics approval was required for this case presentation. 


\section{Consent for publication}

Written consent was obtained was obtained for the publication of this case report from the patient.

\section{Competing interests}

The authors declare no conflict of interests.

Received: 15 June 2021 Accepted: 26 August 2021

Published online: 30 September 2021

\section{References}

1. Beck LH. Jr1, Bonegio RG, Lambeau G, Beck DM, Powell DW, Cummins TD, et al. M-type phospholipase A2 receptor as target antigen in idiopathic membranous nephropathy. N Engl J Med. 2009;361(1):11-21. https://doi. org/10.1056/NEJMoa0810457.

2. Du Y, Li J, He F, et al. The diagnosis accuracy of PLA2R-AB in the diagnosis of idiopathic membranous nephropathy: a meta-analysis. PLoS One. 2014; 9(8):e104936. https://doi.org/10.1371/journal.pone.0104936.

3. Qin W, Beck LH Jr, Zeng C, Chen Z, Li S, Zuo K, et al. Anti-phospholipase A2 receptor antibody in membranous nephropathy. J Am Soc Nephrol. 2011; 22(6):1137-43. https://doi.org/10.1681/ASN.2010090967 Epub 2011 May.

4. Luzardo L, Ottati G, Cabrera J, Trujillo H, Garau M, Caorsi, et al. Substitution of oral for intravenous cyclophosphamide in membranous nephropathy. Kidney360. 2020;1(9):943-9.

5. Hoxha E, Wiech T, Stahl PR, Zahner G, Panzer U, Thomas NM, et al. A Mechanism for Cancer-Associated Membranous Nephropathy. N. Engl. J. Med. 2016;374:1995-6.

6. Caza T, Hassen S, Dvanajscak Z, Kuperman M, Edmondson R, Larsen P, et al. NELL1 is a target antigen in malignancy-associated membranous nephropathy. Kidney Int. 2021;99(4):967-76. https://doi.org/10.1016/j.kint.202 0.07.039 Epub 2020 Aug 20.

\section{Publisher's Note}

Springer Nature remains neutral with regard to jurisdictional claims in published maps and institutional affiliations.

- fast, convenient online submission

- thorough peer review by experienced researchers in your field

- rapid publication on acceptance

- support for research data, including large and complex data types

- gold Open Access which fosters wider collaboration and increased citations

- maximum visibility for your research: over $100 \mathrm{M}$ website views per year

At $\mathrm{BMC}$, research is always in progress.

Learn more biomedcentral.com/submissions 